\title{
Study of successive contrasting monsoons (2001-2002) in terms of aerosol variability over a tropical station Pune, India
}

\author{
R. L. Bhawar ${ }^{1}$ and P. C. S. Devara ${ }^{2}$ \\ ${ }^{1}$ DIFA, Università degli Studi della Basilicata, Viale dell'Ateneo Lucano n. 10, 85100 Potenza, Italy \\ ${ }^{2}$ Indian Institute of Tropical Meteorology, Dr. Homi Bhabha Road, Pashan, Pune, Maharashtra 411 008, India \\ Received: 1 December 2008 - Published in Atmos. Chem. Phys. Discuss.: 16 March 2009 \\ Revised: 30 November 2009 - Accepted: 30 November 2009 - Published: 5 January 2010
}

\begin{abstract}
The present study suggests that aerosols play a major role in cloud formation and affect significantly the precipitation over a regional scale. The study reveals that there is a high variability of aerosol index during a bad monsoon year 2002 , indicating an extension of cycle to more than 100 days from a normal 50 day cycle of absorbing and non-absorbing aerosols over a tropical urban station Pune. Pre-monsoon of 2002 shows a high loading of coarse-mode aerosols (absorbing dust aerosols) which indicate vertical and horizontal temperature variations in turn affecting the seasonal rainfall at a regional scale. Cloud formation highly depends on aerosol concentration, but the activation process is not monotonic. The surface meteorological features help to initiate the cloud process. The surface temperatures were high during the pre-monsoon of 2002 leading to increase of aerosol optical depth as compared to 2001. The effect of surface wind speed, though, complicated to understand, results in low values in 2002 with high aerosol optical depth and vice-versa in 2001.
\end{abstract}

\section{Introduction}

The Indian summer monsoon rainfall (ISMR), defined as the cumulative rainfall over continental India during JuneJuly-August (JJA), having important implications for the socio-economic system of the subcontinent. The JJA rainfall in 2002 was only about $78 \%$ of the seasonal average (679.2 mm, for the period 1871-2002) (Parthasarathy et al., 1995). This affected very severely the agricultural system (http://www.agjournal.com and http://www.fao.org). This is one of the highest deficit monsoon rainfall years in the last hundred years.

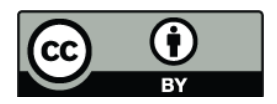

Correspondence to: R. L. Bhawar (rohinibhawar@yahoo.com)
Aerosols originate from a variety of natural and anthropogenic sources and thus exhibit a great variability in both space and time. Airborne particles comprising of dust aerosols alter the local climatic conditions by intercepting sunlight and modifying the energy budget through their behavior of cooling and heating the atmosphere (Liepert, 2002). The presence of an absorbing dust layer results in a substantial decrease in the incoming short-wave radiation, resulting in a major change to the surface energy balance. Results from Indian Ocean Experiment (INDOEX) have already shown that large amount of wind-blown dust particles and other anthropogenically produced aerosols get transported from the Asian landmasses over the ocean surface up to thousands of kilometers away from their sources during the Northern Hemisphere winter seasons (e.g., Ramanathan et al., 2001; Clarke et al., 2002).

Although the main component of atmospheric aerosol that is responsible for the generation and maintenance of the hydrological cycle is not yet clear, it is evident that aerosols are effective agents (Sue et al., 2008, and references therein) and hence, reliable data as well as, systematic study is needed to understand these complex processes (Rosenfeld, 2000, 2008; Devara et al., 2003). Each cloud drop requires an aerosol particle (nucleus) for water vapour to condense upon; clouds could not form otherwise. Thus, aerosols act as Cloud Condensation Nuclei (CCN) or Ice Nuclei (IN). Aerosols affect precipitation in two ways; the presence of more aerosols leads to formation of smaller cloud droplets resulting in brighter clouds that reflect more solar energy back into space. While numerous smaller cloud droplets tend to reduce precipitation and change the extent of cloud cover (Rosenfeld, 2000). Moreover, the aerosol optical depth is one of the parameters that contributes to the radiative forcing at all time and spatial scales, and its mean value at a given location is highly dependent on prevailing environmen$\mathrm{tal} / \mathrm{meteorological}$ conditions and altitude. Thus, influence of surface-meteorological parameters, particularly humidity on

Published by Copernicus Publications on behalf of the European Geosciences Union. 
aerosol composition, play a significant role in the concentration and size distribution of aerosols (Leob and Schuster, 2008). A study in this direction has been carried out using the lidar derived aerosol vertical distributions acquired over Pune (Devara et al., 1994). Thus till present, aerosols mostly have been considered as a problem of climate change which reduces the global warming by their radiative properties, and in air-chemistry by intensifying the pollution and having possible impacts on clouds and rainfall (Podgorny, 2003). Effects of aerosols on atmospheric hydrological cycle in the Asian monsoon region are also investigated by researchers (Lau et al., 2006; Breon, 2006). The successive contrasting monsoon years provide, good opportunity to study various phenomena involved in monsoon dynamics. In the present study, the importance and behavior of aerosols during two consecutive years of active and weak monsoon activity has been highlighted. The focus will be in terms of aerosol optical, physical and radiative properties, derived from coincident ground-based multi-filter solar radiometer, satelliteborne measurements and meteorological conditions over a tropical urban station Pune. The study reported over the station, Pune $\left(18^{\circ} 32^{\prime} \mathrm{N}, 73^{\circ} 51^{\prime} \mathrm{E}, 559 \mathrm{~m}\right.$ a.m.s.l.), India in this paper has an urban environment and the aerosol type present over this site is considered to be a mixture of water-soluble, dust and soot-like aerosols. Soil dust is the major source of aerosol pollutants present over the experimental station. The experimental site is located at an elevation of $573 \mathrm{~m}$ above mean sea level and surrounded by hillocks forming a valley like configuration. Because of the typical terrain the circulation processes show its effect mostly in the lower levels of the atmosphere.

\section{Data deduction}

The data used in the present study comprise of a MICROTOPS-II solar radiometer (MTP)-observed aerosol optical depth, Total Ozone Mapping Spectrometer (TOMS)derived aerosol index (AI) and concurrent meteorological parameters recorded during two successive contrasting monsoon seasons of 2001 and 2002 over Pune, India. The cloud effective radius and cloud optical depth derived from MODIS sensor also have been utilized to study the indirect effect of aerosols. The MTP is a portable, hand-held, multi-channel solar radiometer, which had been operated at the Indian Institute of Tropical Meteorology (IITM), Pune. MTP provides columnar: aerosol optical depth (AOD), ozone (TCO) and precipitable water content (TWC) (Morys et al., 2001; Devara et al., 2001). It measures the extinction of solar radiation through atmosphere by aerosols against the incident solar radiation and gives AOD at 380, 440, 500, 675, 870 and $1020 \mathrm{~nm}$. The uncertainties involved in sun-photometer calibration typically range between 0.005 and 0.02 . When the accuracy in the aerosol optical depth measurement is 0.005 the error in calibration of the sun-photometer should be less than $\pm 0.5 \%$ when the air mass is unity (Shaw, 1983; Harrison et al., 1994; Ehsani et al., 1998; Holben et al., 1998). The $V_{0}$ measurements taken from selected clear-sky Langley plots fit the line to within $0.1 \%$. This implies that calibrations remain constant for more than a year. The MICROTOPS-II has been used in varied temperatures and humidity ranges and also on ship cruises, but due to the presence of Barr filters which are supposed to have unlimited lifetime the calibrations show no sign of filter decay. The error which results in the aerosol optical depth measurements for land based measurements for $380,440,500,675$ and $870 \mathrm{~nm}$ is $0.023,0.018$, $0.021,0.012$ and 0.023 , respectively (Morys et al., 2001; Devara et al., 1996). The MICROTOPS-II-derived AODs at different wavelengths were utilized to calculate the size index (v) parameter and aerosol loading over the station.

Space-borne sensors provide a good temporal and spatial coverage. The satellite based TOMS sensor has been flown aboard since 1978 on various platforms for monitoring global total column ozone by studying both incoming solar radiation and back-scattered radiation in the UV-region. The algorithm for TOMS detection of aerosol and clouds from the back-scattered UV radiance measurement is based on the residue theory described in Herman et al. (1997) and Torres et al. (1998). The residue method is based on the principle that for fixed $380 \mathrm{~nm}$ radiance the $I_{340} / I_{380}$ spectral contrast is largest for non-absorbing aerosol and clouds and decreases with increasing absorption. UV absorbing aerosols (dust, smoke, soot) produce smaller contrast than predicted by pure Rayleigh scattering atmospheric model, consequently they yield positive residues. In contrast the non-absorbing aerosols (sulfate and sea-salt particles) produce greater contrast and negative residues. As suggested by Herman et al. (1997), TOMS data can be used to derive Aerosol Index (AI).

$\mathrm{AI}=-100\left[\log _{10}\left(I_{331} / I_{360}\right)_{\text {meas }}-\log _{10}\left(I_{331} / I_{360}\right)_{\text {cal }}\right]$

where, $I_{\text {meas }}$ is the measured back-scattered radiance and $I_{\text {cal }}$ is the calculated radiance for a pure Rayleigh atmosphere. The positive AI represents absorbing aerosols while negative AI corresponds to less-absorbing or non-absorbing aerosols. TOMS used the radiance in UV wavelengths as it is advantageous to characterize aerosols over all surface types. The effective Lambertian equivalent surface reflectivity and the aerosol index are not physical quantities. Because of this, no algorithmic error sources have been included. Nominal instrument calibration errors of $1.5 \%$ at $360 \mathrm{~nm}$ and $0.75 \%$ at $331 \mathrm{~nm}$ relative to $360 \mathrm{~nm}$ have been assumed. Evidence of uncorrected diffuser degradation drives the errors in longterm mean for the reflectivity and aerosol index, but there is no significant effect on derived ozone (http://jwocky.gsfc. nasa.gov/eptoms/dataqual/nominal.html).

MODIS (MODerate resolution Imaging Spectroradiometer) was flown on Terra and Aqua platforms in 1999 and 2002 respectively. It monitors the Earth in 36 discrete bands with a high spatial resolution of $250 \mathrm{~m}, 500 \mathrm{~m}$ and $1000 \mathrm{~m}$ 

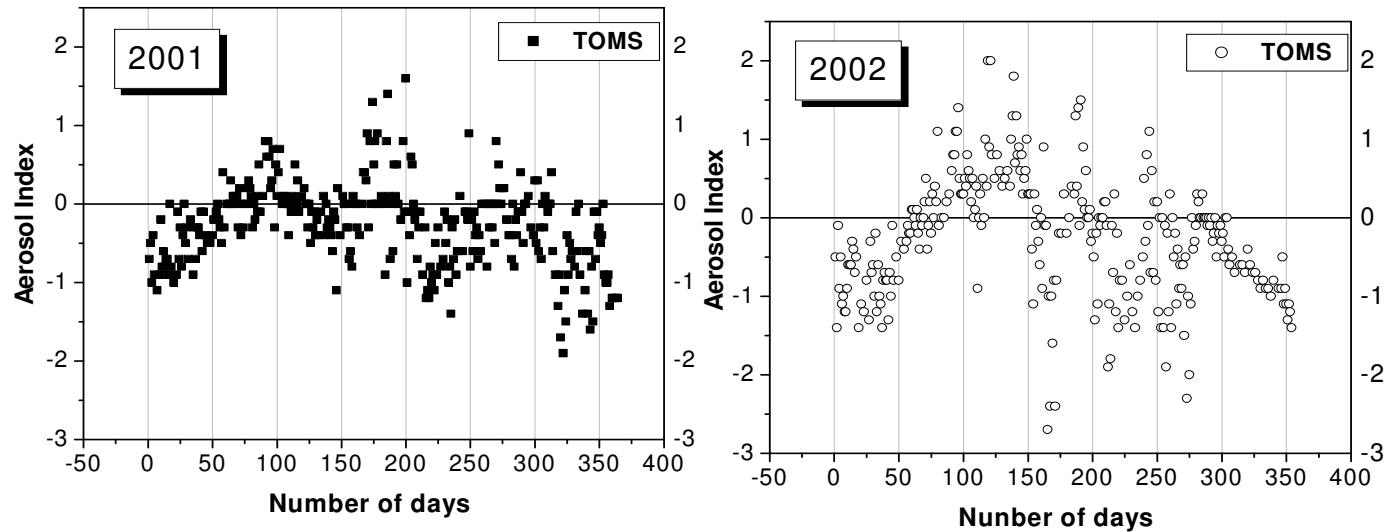

Fig. 1. Aerosol index variations over Pune during two contrasting monsoon years, 2001 and 2002.

in different bands. The aerosol optical thickness products obtained from MODIS over land are accurate within their calculated uncertainties $( \pm 0.05 \pm 0.20$ tau $)$, except in situations when there is cloud cover (cloud contamination), over surfaces with sub-pixel surface water such as coastal areas and marshes, and over surfaces with sub-pixel snow or ice cover. Complete details of the original algorithms and parameters derived over land and/or ocean are given in the work of Kaufman et al. (1997a, b) and Tanré et al. (1997). The near-infrared total-column precipitable water is very sensitive to boundary-layer water vapor since it is derived from attenuation of reflected solar light from the surface. This data product is essential to understanding the hydrological cycle, aerosol properties, aerosol-cloud interactions, energy budget, and climate (Remer et al., 2005). The cloud effective radius (CER), which is an area-weighted mean radius of the cloud droplets, is determined as;

$r_{e}=\frac{\int_{0}^{\infty} r^{3} n(r) d r}{\int_{0}^{\infty} r^{2} n(r) d r}$

where $r=$ particle radius; $n(r)=$ particle size distribution (number of particles per $\mathrm{cm}^{2}$ with radius in the range $r$ and $r+d r$ microns). Thus derived CER from MODIS is considered to strengthen the quantification of the aerosol effect on cloud cover (Kaufman et al., 1997a, b).

\section{Discussion of results}

In addition to the time series of AI for the entire year, both TOMS and MICROTOPS-II data are also grouped under different months and seasons separately for each year. The behaviour of optical and physical properties of aerosols in conjunction with concurrent meteorological parameters during 2001 and 2002 is discussed in the sub-sections to follow.

\subsection{Variations in aerosol composition}

Figure 1 illustrates the time evolution of AI over Pune, a fast growing urban station, during 2001 and 2002. The variations in AI exhibit, by and large, bell-shape with maximum (positive AI) during the pre-monsoon and minimum (negative AI) during the winter months for both the years. Broadly, the plot clearly shows the dominance of absorbing aerosols during the pre-monsoon and less- or non-absorbing aerosols during winter. The negative values indicate the non-absorbing aerosols (such as sulphate and sea salt) while positive values indicate absorbing aerosols (such as mineral dust and smoke), and the near-zero values of AI are due to presence of clouds. In 2001 (50 day oscillation) the variation starts with non-absorbing aerosols in winter followed by absorbing aerosols during summer, while in monsoon it has a mixed type of situation with near-zero values indicating mostly the presence of clouds. But for 2002 three prominent cycles, each of more than 100 days are observed; it starts with nonabsorbing switching to more absorbing aerosols and back to non-absorbing aerosols. The presence of absorbing aerosols in summer months over Pune is mostly due to the dust transport from the semi-arid region (Pandithurai et al., 2004). The absorbing dust aerosols cause the vertical and horizontal temperature variations during pre-monsoon season, which in turn alter the seasonal rainfall over the particular region. They also tend to suppress precipitation under certain meteorological conditions. The dust events lead to enhanced heating rates in the lower troposphere (Pandithurai et al., 2008).

Moreover, most important feature that can be seen in the figure is that the variation in AI is significantly large in the year 2002 (drought) as compared to that in 2001 (active monsoon). In order to examine the size distribution of aerosols in 2001 and 2002 the Angstrom parameters were studied. 

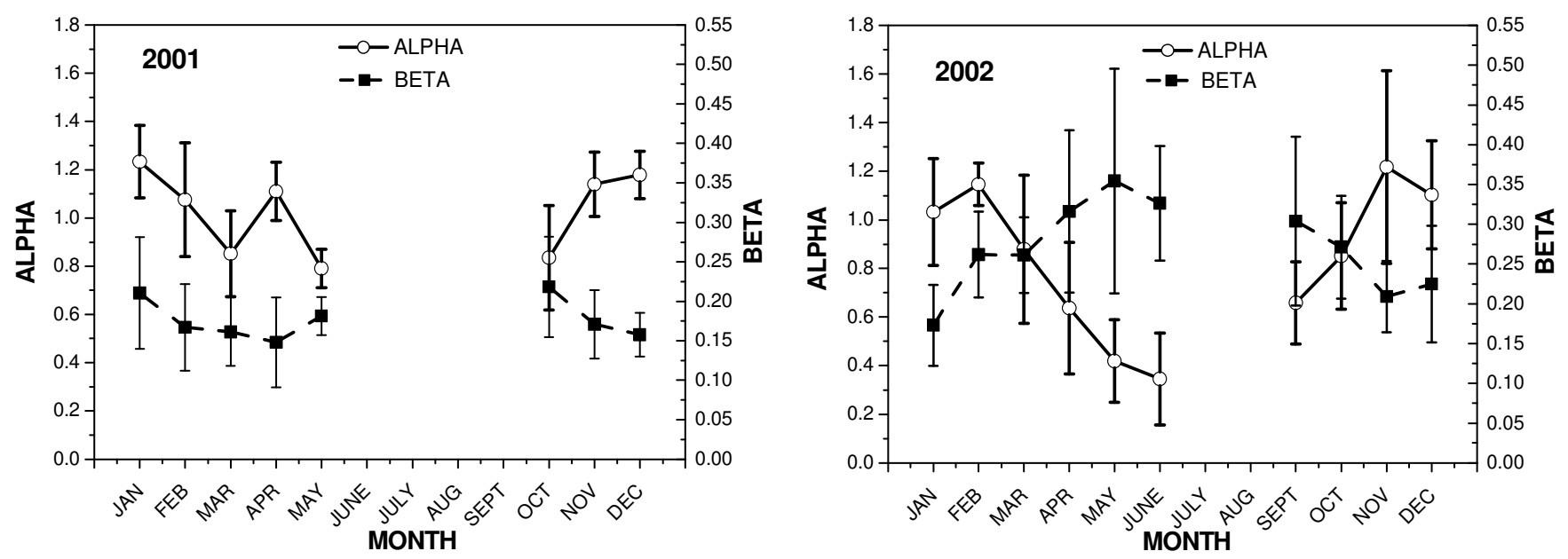

Fig. 2. Monthly mean variation in $\alpha$ and $\beta$ observed during 2001 and 2002.

\subsection{Variations in aerosol size distribution}

Monthly mean values of $\alpha$ and $\beta$ obtained from the relation, $\tau=\beta \lambda^{-\alpha}$, where $\alpha$ is wavelength exponent, while $\beta$ is Angstrom coefficient are seen plotted in Fig. 2 for both 2001 and 2002. The $\alpha$ value is an indicator of size while $\beta$ indicates the loading of aerosols. Angstrom wavelength exponent gives an indication of the origin or type of aerosol. Aerosols of maritime, desert, or volcanic origin, for example, are relatively large and are associated with smaller values of $\alpha$ (von Hoyningen-Huene et al., 1999; Chiapello et al., 2000; Maring et al., 2000; Smirnov et al., 2000; Holben et al., 2001). Aerosols from biomass burning or anthropogenic sources (e.g. industrial or vehicular emissions), in contrast, are typically relatively small and are thus represented by higher values of $\alpha$ (e.g. Deuzé et al., 2001; Eck et al., 2001; Formenti et al., 2001; Holben et al., 2001). The parameters $\alpha$ and $\beta$ were calculated using the spectral distribution of AOD obtained from MICROTOPS-II. The gap in the data during the monsoon months is due to unfavourable sky conditions under which reliable data from MICROTOPS-II could not be obtained due to presence of clouds. Both plots show larger size index, $(v=\alpha+2)$ values indicating greater concentration of sub-micron aerosol particles during the winter and smaller $v$ values suggesting coarse-mode particles during the pre-monsoon months.

Besides the usual behaviour of aerosol loading (larger $\beta$ value) during pre-monsoon months and relatively smaller values during winter, larger values of $\beta$ and smaller values of $\alpha$ during winter as compared to the pre-monsoon months in certain years are attributed partly due to intense haze formation due to elevated temperature inversions and associated trapping of local anthropogenic aerosols. A significant difference is seen between 2002 and 2001. The value of $\alpha$ in pre-monsoon is 0.2 for 2002 as compared to 0.8 in 2001, which implies presence of more accumulation-mode parti- cles in 2001 than in 2002 suggesting more loading of coarsemode aerosols in 2002 than in 2001 during pre-monsoon. Thus more number of accumulation-mode particles; adequate loading of aerosol amount in atmosphere during premonsoon triggered a good cloud formation process in 2001 which yielded a good amount of precipitation. In 2002, the situation was exactly opposite with presence of coarse-mode particles; absorbing dust aerosols as seen from AI data from TOMS. The interesting finding is that more absorbing dust aerosols were present in 2002 , but the total columnar water vapour content was also low by almost 0.5 to $1 \mathrm{~cm}$ in 2002 than in 2001 as obtained from MODIS satellite data (Bhawar, 2008). Large number of absorbing dust aerosols, heat the lower troposphere but cool surface, and they compete for small amount of water vapor resulting in less amount of rain (Ramanathan et al., 2001). In order to further strengthen and confirm, the above point, monthly mean variations in cloud effective radius (CER) for 2001 and 2002 are shown plotted in Fig. 3, where three epochs are seen in Fig. 3. In 2001 and 2002 the CER goes on increasing from pre-monsoon to monsoon months as during the monsoon months the cloud formation starts, with a further decrease of CER in winter months.

But the CER in 2002 during the monsoon months is less as compared to 2001 which suggests that the cloud formation was less in 2002 as opposed to 2001. Rather we can say clouds formed but dissipated in shorter period. It is observed at Pune, that after the onset of monsoon in June, there is more rain in July and August in the normal years and then intensity decreases in September. It is evident in the CER plot that there is a decrease in CER in 2002 for the July and August months. Larger the CER, more the size of cloud droplet and more chances for rain occurrence, while less CER leads to cloud dissipation and hence less rain. Figure 4 shows monthly mean variation in cloud optical depth (COD) during 2001 and 2002. As suggested by Storelvmo 


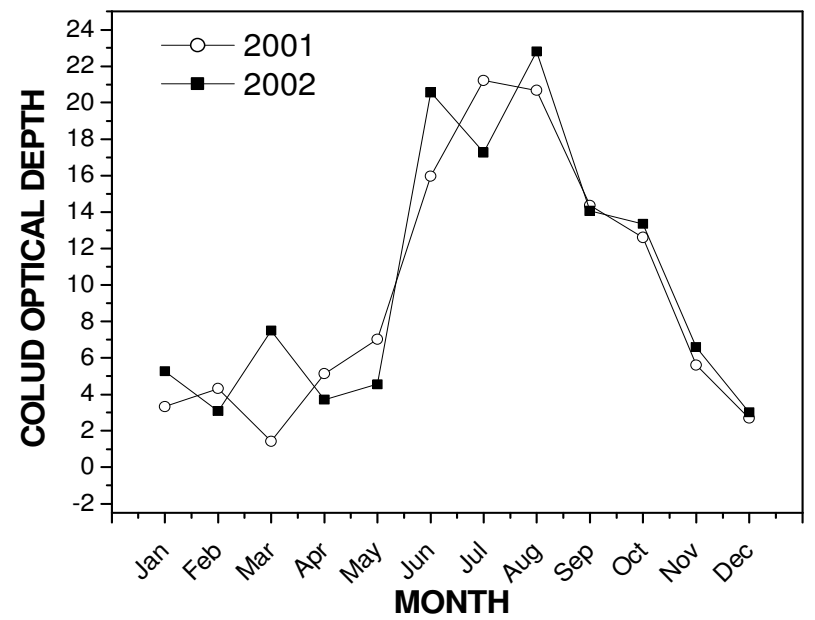

Fig. 3. Monthly variation in cloud optical thickness for 2001 and 2002.

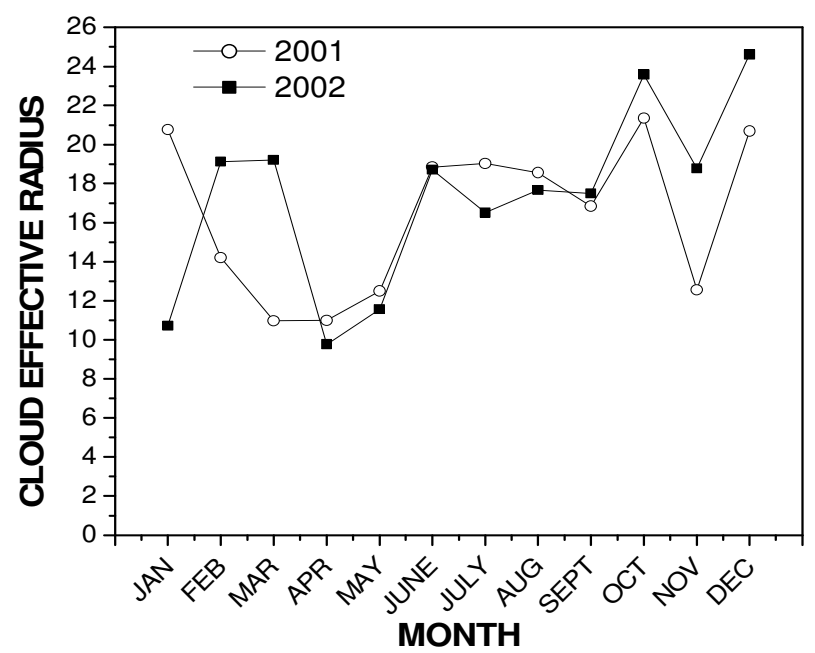

Fig. 4. Monthly variation in cloud effective radius for 2001 and 2002.

et al. (2006), COD directly correlates with rainfall. In the present study, as the CER increases COD also increases and more COD results in more rainfall and vice-versa. It is distinctly seen from the Fig. 4 that in the month of July, when maximum rainfall occurred in Pune COD was less in 2002 as compared to 2001, and amounts to rainfall of $118 \mathrm{~mm}$ in 2001 and $26 \mathrm{~mm}$ in 2002. As the processes responsible for these differences have an important bearing on the regional atmosphere, the local meteorological conditions are also important, which are discussed below.

\subsection{Variations in concurrent meteorological parameters}

The normal weather at the experimental site during the premonsoon season (March, April, May) is very hot with mostly gusty surface winds and the dust content in the atmosphere is
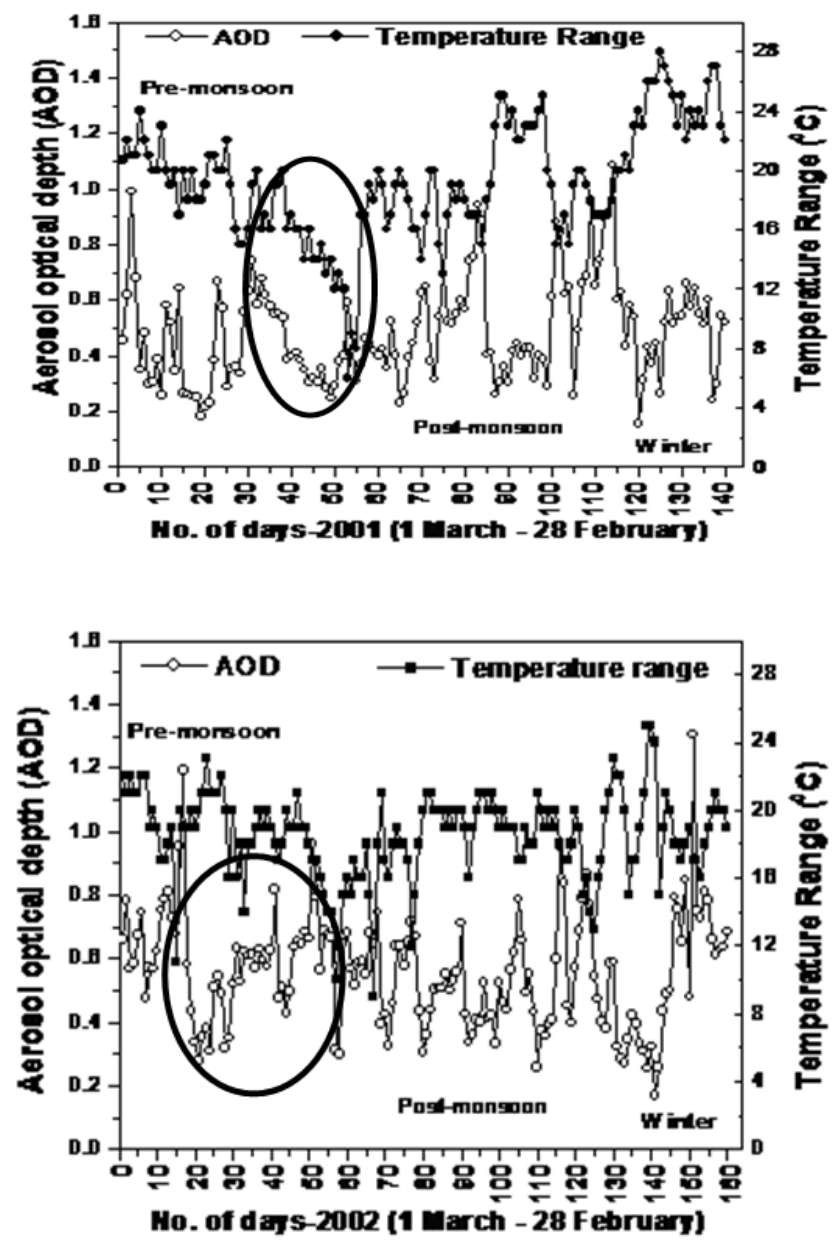

Fig. 5. Day-to-day variations in both $\mathrm{AOD}$ and temperature range during pre-monsoon, post-monsoon and winter season.

at a maximum. The air flow in the lower troposphere is predominantly westerly during the south-west (SW) monsoon season (June, July, August, September), which brings a large influx of moist air from the Arabian Sea. Fair-weather conditions with clear skies, light surface winds and very low humidity exist during the winter season (December, January, and February). Low-level inversions during the morning and evening hours, and dust haze during the morning hours occur during this season (Devara et al., 2005). In Figs. 5, 6 and 7 in the $\mathrm{x}$-axis the numbers of days are the available number of days in terms of AOD and temperature range, relative humidity and wind speed respectively starting from 1 March and ending on 28 February. The monsoon period when the AOD is not available is not included in the Figs. 5, 6 and 7. The daytime diurnal variations in surface temperature range, which is difference between maximum and minimum temperature, for the pre-monsoon, post-monsoon and winter months of 2001 and 2002 are shown plotted in Fig. 5. A significant annual variation in all the above three parameters with maximum AOD in pre-monsoon months and relatively 

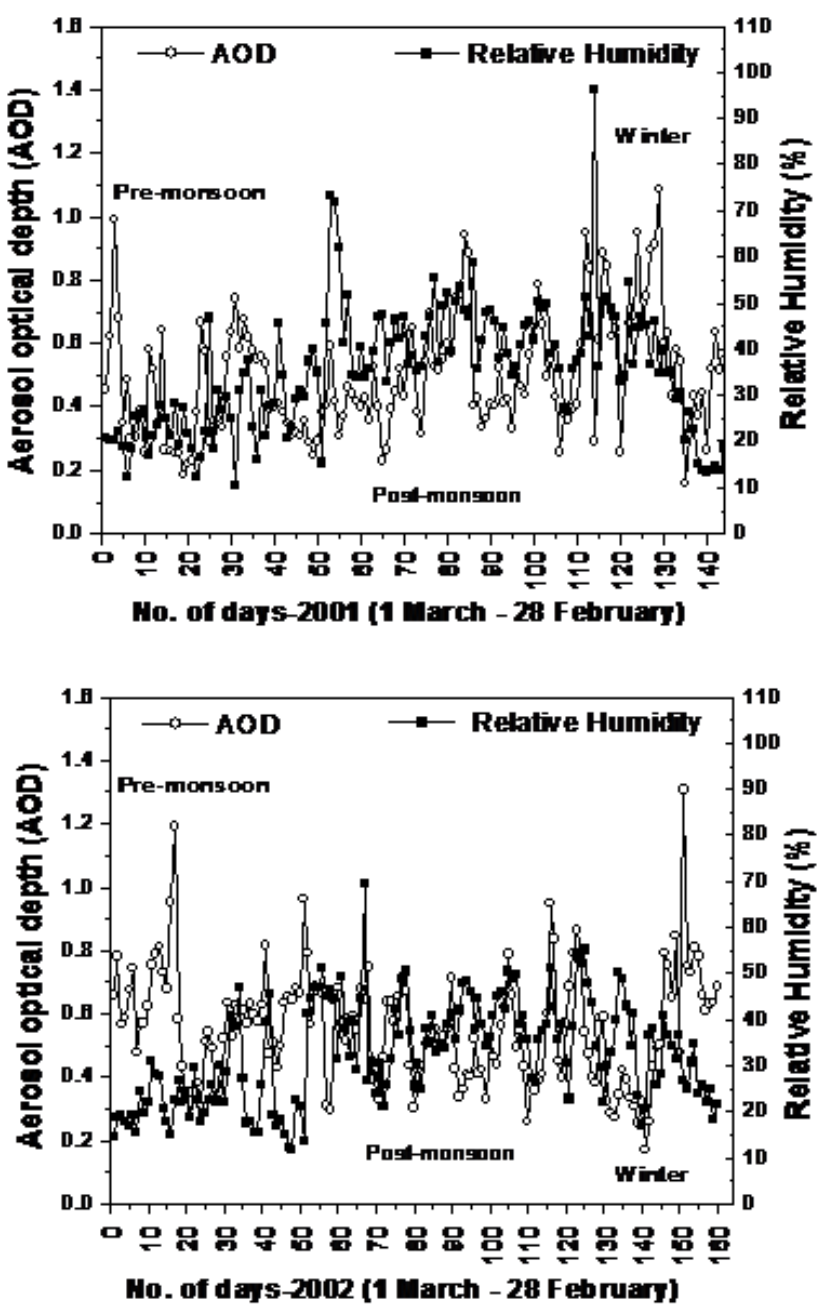

Fig. 6. Day-to-day variations in both AOD and relative humidity during pre-monsoon, post-monsoon and winter seasons of 2001 and 2002.

minimum in winter months is quite clear from the figure. The high convective activity and frequent occurrence of dust storms are responsible for the higher AODs during the premonsoon. Subsequently, the AOD values attain minimum due to cloud-scavenging and rain-washout processes during the monsoon, and thereafter they slowly build-up during post-monsoon and winter months (due to haze) and becomes maximum again in summer. The influence of temperature on AOD is quite clear from the figure. Normally, increase in surface temperature causes lifting of aerosols that effects size distribution and results in higher AOD. The variations in $\mathrm{AOD}$ at $380 \mathrm{~nm}$ and concurrent surface-level temperature range for 2001 and 2002 seem to follow each other. In the 2001 plot for variations of AOD with surface temperature range during the pre-monsoon, there is a steep decrease in surface temperature from $23^{\circ} \mathrm{C}$ to $8^{\circ} \mathrm{C}$ (circled in the figure). From the post-monsoon to winter there is again an
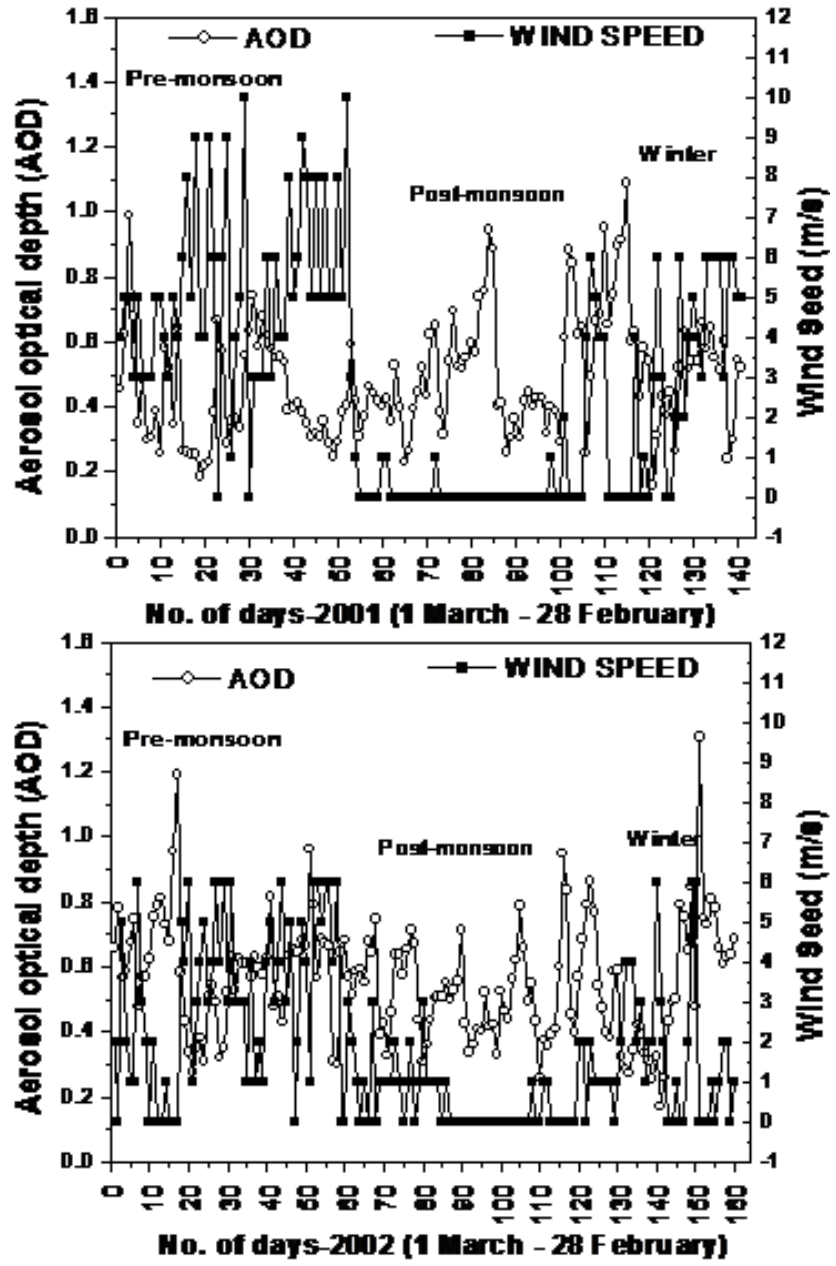

Fig. 7. Day-to-day variations in both AOD and wind speed during pre-monsoon, post-monsoon and winter seasons of 2001 and 2002.

increase in surface temperature from $8^{\circ} \mathrm{C}$ to $28^{\circ} \mathrm{C}$. Correspondingly there are larger AOD variations associated with surface temperature variations. The plot for AOD and surface temperature range for 2002 shows a drastically different behaviour. There is very less variation in surface temperature range from $16^{\circ} \mathrm{C}$ to $24^{\circ} \mathrm{C}$ throughout the pre-monsoon, post-monsoon and winter. The higher value of surface temperature in the pre-monsoon supports the presence of absorbing dust aerosols from the AI values of TOMS. The surface temperature is high during 2002 compared to 2001, and AOD also shows a continuous increase in 2002 than in 2001.

The variations in daily mean AOD at $380 \mathrm{~nm}$ and surface relative humidity during pre-monsoon, post-monsoon and winter seasons of 2001 and 2002 are depicted in Fig. 6. Condensation of water vapour takes place on the aerosols with increasing relative humidity and evaporation of water vapour in aerosols takes place with decreasing relative humidity. In general, increase in relative humidity leads to particle growth and hence an increase in AOD. Thus the aerosol particles 
grow as relative humidity increases and shrink as relative humidity decreases. But the rate of growth in response to increase in relative humidity is not equal to rate of shrink in response to decrease in relative humidity. Due to growth of particle the surface area increases and in turn reflects in high AOD. As the surface relative humidity increases the AOD also increase for hygroscopic aerosols, which are observed mostly during March and April months of 2001. In 2001 plot, for AOD and surface relative humidity there is a rise of relative humidity from $20 \%$ to about $60 \%$ in pre-monsoon and post-monsoon while it drops down to $20 \%$ in winter. In 2002 , the surface relative humidity during pre-monsoon is between $20 \%$ and $30 \%$ with a high aerosol loading, while in post-monsoon and winter it varies between $35 \%$ and $50 \%$. During winter months the surface relative humidity is less and AOD shows an increase which is due to the presence of haze in atmosphere.

Figure 7 displays the daily mean variations in concurrent AOD and surface wind speed during pre-monsoon, postmonsoon and winter months of 2001 and 2002. The influence of wind speed on aerosol optical depth in the whole atmospheric column is complex (Platt and Patterson, 1986; Villevalde et al., 1994; Smirnov et al., 1995; Moorthy et al., 1997; Kusmierczyk-Michulec et al., 1999). The correlation between wind speed and aerosols also depends on the size of aerosols. Different wind speed affects different size of particles (Smirnov et al., 2003). Overall comparison of surface wind speed for pre-monsoon of 2001 and 2002 shows higher surface wind speed values, varying from $4 \mathrm{~m} / \mathrm{s}$ to $10 \mathrm{~m} / \mathrm{s}$ in 2001 as compared to those from $1 \mathrm{~m} / \mathrm{s}$ to $6 \mathrm{~m} / \mathrm{s}$ in 2002 . The variation in surface wind speed for post-monsoon and winter is almost same in both the years. The association between AOD and surface wind speed is complicated, because it may either remove aerosols from or may bring in fresh aerosols to the experimental site. The correlation between aerosol concentration and surface wind speed is relatively high in lower altitudes, which implies that the effect of surface wind speed on aerosol concentration is more significant at lower altitudes (Parameshwaran et al., 1995). In the present study, it is found that whenever the surface wind speed is high the AOD value is low and vice-versa. Thus higher surface wind speed values are associated with removal of aerosols and lower surface wind speed with addition of aerosols in both the years. Thus compared to 2001, 2002 was associated with slightly more aerosol loading. In 2001 pre-monsoon though the surface wind speeds are high the AOD is not as high as expected which indicates the removal of aerosols from the experimental site. While in the post-monsoon and winter there is a build up of aerosol loading with low surface wind speed values indicating inflow of aerosols from the neighbouring areas. There is an opposite correlation between AOD and wind speed in 2002 same as seen in 2001. In 2002 pre-monsoon surface wind speed is not as high as it was in 2001 but AOD is high as compared to 2001. There is also high aerosol loading throughout post-monsoon and winter months.

\section{Conclusions}

It may be concluded that the influence of aerosols on monsoon activity mainly depends on dynamics or microphysics or both. From the present study, it may be inferred that the impact of aerosols on the hydrological cycle, in some sense, is a region-specific phenomenon, and it primarily relies on relative dominance of the type (scattering/absorbing and the associated mixing due to transport processes) and composition of aerosols at a particular location. Moreover, it depends on which process (whether dynamics or microphysics) ultimately drives the monsoon circulation. Keeping in view of large heterogeneity in aerosol production/removal processes and short lifetime in the troposphere, it is difficult to generalize the impact of aerosols on the hydrological cycle. Such studies need dense network of observations besides the satellite data in order to isolate the regional effects from the global and also the anthropogenic effects from the natural ones. Thus, this study shows role of aerosols through their optical and micro-physical properties and their effects on the hydrological cycle; more work in this direction is planned in the future studies. The present study helps understanding the importance of aerosols in the hydrological cycle on a regional scale over a tropical station, Pune, India. Moreover, the study reveals a cycle of 50 days in the variations in the absorbing dust aerosols and non- absorbing aerosols during the normal monsoon condition while during the weak monsoon, this cycle extends to more than 100 days. Larger variations in the aerosol index values was observed during weak monsoon year (2002) as compared to active monsoon year (2001). As estimated from the Angstrom coefficient, more loading of absorbing dust aerosols was found in 2002 as compared to 2001. The CER showed smaller values, implying less cloud formation or early dissipation of clouds and hence less precipitation in 2002. The surface meteorological features showed different behaviour in the two successive contrasting monsoon years; particularly surface temperature showed increase in 2002 and hence increase in AOD than in 2001; and surface wind speed exhibited higher values in 2001 resulted in removal of aerosols from the site than in 2002.

Acknowledgements. The authors are highly thankful to the anonymous reviewers for their critical and valuable comments and suggestions. The cooperation and support from the Members of the IITM Lidar and Radiation Group are gratefully acknowledged. Thanks are also due to the Director, IITM, Pune, India for providing infrastructure facilities. One of the authors (RLB) is grateful to Paolo Di Girolamo for helpful suggestions during the communication of this paper.

Edited by: J. Quaas 


\section{References}

Breon, F.: How do aerosols affect cloudiness and climate?, Science, 313, 623-624, 2006.

Clarke, A. D., Howell, S., Quinn, P. K., Bates, T. S., Ogren, J. A., Andrews, E., Jefferson, A., et al.: The INDOEX aerosol: A comparison and summary of microphysical,chemical,and optical properties observed from land,ship, and aircraft, J. Geophys. Res.-Atmos., 107(D19), doi:10.1029/2001JD000572, 2002.

Chiapello, I., Goloub, P., Tanré, D., Marchand, A., Herman, J., and Torres, O.: Aerosol detection by TOMS and POLDER over oceanic regions, J. Geophys. Res., 105(D6), 7133-7142, 2000.

Deuzé, J. L., Bréon, F. M., Devaux, C., Goloub, P., Herman, M., Lafrance, B., Maignan, F., Marchand, A., Nadal, F., Perry, G., and Tanré, D.: Remote sensing of aerosols over land surface from POLDER-ADEOS-1 polarized measurements, J. Geophys. Res., 106(D5), 4913-4926, 2001.

Devara, P. C. S., Raj, P. E., Sharma, S., and Pandithurai, G.: Lidarobserved long-term variations in urban aerosol characteristics and their connection with meteorological parameters, Intl. J. Climatol., 14, 581-591, 1994.

Devara, P. C. S., Pandithurai, G., Raj, P. E., Sharma, S., et al.: Investigation of aerosol optical depth variations using spectroradiometer at an urban station, Pune, India, J. Aerosol Sci., 27(4), 621-632, 1996.

Devara, P. C. S., Maheskumar, R. S., Raj, P. E., Dani, K. K., and Sonbawne, S. M.: Some features of column aerosol optical depth, ozone and precipitable water content observed over land during the INDOEX-IFP99, Meteorol. Z., 10, 123-130, 2001.

Devara, P. C. S., Raj, P. E., Pandithurai, G., Dani, K. K., and Maheskumar, R. S.: Relationship between lidar-based observations of aerosol content and monsoon precipitation over a tropical station, Pune, India, Meteorol. Appl., 10, 253-262, 2003.

Devara, P. C. S., Saha, S. K., Raj, P. E., Sonbawne, S. M., Dani, K. K., Tiwari, Y. K., and Maheskumar, R. S.: A Four-Year Climatology of Total Column Tropical Urban Aerosol, Ozone and Water Vapor Distributions over Pune, India, Aerosol Air Qual. Res., 5, 103-114, 2005.

Eck, T. F., Holben, B. N., Ward, D. E., Dubovik, O., Reid, J. S., Smirnov, A., Mukelabai, M. M., Hsu, N. C., O’Neill, N. T., and Slutsker, I.: Characterization of the optical properties of biomass burning in Zambia during the 1997 ZIBBEE field campaign, J. Geophys. Res., 106(D4), 3425-3448, 2001.

Ehsani, A. R., Reagan, J. A., and Erxleben, W. H.: Design and performance of an automated 10-channel solar radiometer instrument, J. Atmos. Oceanic Technol., 15, 697-707, 1998.

Formenti, P., Andreae, M. O., Andreae, T. W., Galani, E., Vasaras, A., Zerefos, C., Amiridis, V., Orlovsky, L., Karnieli, A., Wendisch, M., Wex, H., Holben, B. N., Maenhaut, W., and Lelieveld, J.: Aerosol optical properties and large-scale transport of air masses: observations at a coastal and a semiarid site in the eastern Mediterranean during summer 1998, J. Geophys. Res., 106(D9), 9807-9826, 2001.

Harrison, L., Michalsky, J., and Berndt, J.: Automated multifilter rotation shadowband radiometer: An instrument for optical depth and radiation measurements, Appl. Optics, 33, 5188-5125, 1994.

Herman, J. R., Bhartia, P. K., Torres, O., Hsu, C., Seftor, C., and Celarier, E.: Global distribution of UV- absorbing aerosol from Nimbus 7/TOMS data, J. Geophys. Res., 102(D14), 1691116922, 1997.
Holben, B. N., Eck, T. F., Slutsker, I., et al.: AERONET - A federated instrument network and data archive for aerosol characterization, Rem. Sens. Environ., 66, 1-16, 1998.

Holben, B. N., Tanré, D., Smirnov, A., Eck, T. F., Slutsker, I., Abuhassan, N., Newcomb, W. W., Schafer, J. S., Chatenet, B., Lavenu, F., Kaufman, Y. J., Vande Castle, J., Setzer, A., Markham, B., Clark, D., Frouin, R., Halthore, R., Karnieli, A., O’Neill, N. T., Pietras, C., Pinker, R. T., Voss, K., and Zibordi, G.: An emerging ground-based aerosol climatology: aerosol optical depth from AERONET, J. Geophys. Res., 106(D11), 12067-12097, 2001.

Kaufman, Y. J., Tanrée, D., Remer, L. A., Vermote, E., Chu, A., and Holben, B. N.: Operational remote sensing of tropospheric aerosol over land from EOS moderate resolution imaging Spectroradiometer, J. Geophys. Res., 102, 17051-17067, 1997a.

Kaufman, Y. J., Wald, A. E., Remer, L. A., Bo-Cai Gao, Rong-Rong Li, and Flynn, L.: The MODIS 2.1-mu m channel-correlation with visible reflectance for use in remote sensing of aerosol, IEEE T. Geosci. Remote, 35, 1286-1298, 1997b.

Kusmierczyk-Michulec, J., Krugerr, O., and Marks, R.: Aerosol influence on the sea viewing wide-field of-view sensor bands: Extinction measurements in a marine summer atmosphere over the Baltic Sea, J. Geophys. Res., 104, 14293-14307, 1999.

Lau, K. M., Kim, M. K., and Kim, K. M.: Asian monsoon anomalies induced by aerosol direct effects - the role of the Tibetan Plateau, Clim. Dynam., 26, 855-864, doi:10.1007/s00382-00601 14-2, 2006.

Liepert, B. G.: Observed reductions of surface solar radiation at sites in the United States and worldwide from 1961 to 1990 , Geophys. Res. Lett., 29(10), 1421, doi:10.1029/2002GL014910, 2002.

Loeb, N. G. and Schuster, G. L.: An obervational study of the relationship between cloud, aerosol and meteorology in broken low-level cloud conditions, J. Geophys. Res., 113, D14214, doi:10,.1029/2007JD009763, 2008.

Maring, H., Savoie, D. L., Izaguirre, M. A., McCormick, C., Arimoto, R., Prospero, J. M., and Pilinis, C.: Aerosol physical and optical properties and their relationship to aerosol composition in the free troposphere at Izana, Tenerife, Canary Islands, during July 1995, J. Geophys. Res., 105(D11), 14677-14700, 2000.

Moorthy, K. K., Satheesh, S. K., and Murthy, B. V. K.: Investigations of marine aerosols over the tropical Indian ocean, J. Geophys. Res., 102, 18827-18842, 1997.

Morys, M., Mims Ii, F. M., Hagerup, S., Anderson, S. E., Baker, A., and Walkup, T.: Design, calibration, and performance of MICROTOPS-II handheld ozone monitor and sun photometer, J. Geophys. Res., 106, 14573-14582, 2001.

Pandithurai, G., Pinker, R. T., Takamura, T., and Devara, P. C. S.: Aerosol radiative forcing over an urban station in India and its comparison with INDOEX estimates, Geophys. Res. Lett., 31, L12107, doi:10.1029/2004GL019702, 2004.

Pandithurai, G., Dipu, S., Dani, K. K., Tiwari, S., Bisht, D. S., Devara, P. C. S., and Pinker, R. T.: Aerosol radiative forcing during dust events over New Delhi, India, J. Geophys. Res., 113(1-13), D13209, doi:10.1029/2008JD009804, 2008.

Parameshwaran, K., Vijayakumar, G., Krishna Murthy, B. V., and Krishna Moorthy, K.: Effect of wind speed on mixing region aerosol concentrations at a tropical coastal station, J. Appl. Meteorol., 34, 1392-1397, 1995. 
Parthasarathy, B., Munot, A. A., and Kothawale, D. R.: All India monthly and seasonal rainfall series: 1871-1993, Theor. Appl. Climatol., 49, 217-224, 1995.

Platt, C. M. R. and Patterson, G. R.: The interpretation of baseline atmospheric turbidity measurements at Cape Grim, Tasmania, J. Atmos. Chem., 4, 187-197, 1986.

Podgorny, J. A.: Three-dimensional radiative interactions in a polluted broken cloud system, Geophys. Res. Lett., 30(14), 1771, doi:10.1029/2003GL017287, 2003.

Ramanathan, V., Crutzen, P. J., Leliveld, J., Mitra, A. P., Althausen, D., Anderson, J., Cantrell, W., Cass, G. R., Chung, G. E., Clarke, A. D., Coakley, J. A., Collins, W. D., Conat, W. C., Dulac, F., Heintzenberg, J., Heymsfield, A. J., Holben, B., Howell, S., Hudson, J., Jayaraman, A., Kiehl, J. T., Krishnamurti, T. N., Lubin, D., McFarquhar, G., Novakov, T., Ogren, J. A., Podgorny, I. A., Prather, K., Priestley, K., Prospero, J. M., Quinn, P. K., Rajeev, K., Rasch, P., Rupert, S., Sadourny, R., Satheesh, S. K., Shaw, G. E., Sheridan, P., and Valero, F. P. J.: Indian Ocean Experiment: An integrated analysis of the climate forcing and effects of the great Indo-Asian haze, J. Geophys. Res., 106(D22), 2837128398, 2001.

Remer, L. A., Kaufman, Y. J., Tanre, D., et al.: The MODIS aerosol algorithm, products, and validation, J. Atmos. Sci., 62, 947-973, 2005.

Rohini, L. B.: Aerosol Characterization using Satellite and Groundbased Measurements, Ph.D. thesis, University of Pune, Pune, India, 2008.

Rosenfeld, D.: Suppression of rain and snow by urban and industrial air pollution, Science, 287, 1793-1796, 2000.

Rosenfeld, D., Lohmann, U., Raga, G. B., O’Dowd, C. D., Kulmala, M., Fuzzi, S., Reissell, A., and Andeae, M. O.: Flood or drought: How do aerosols affect precipitation?, Science, 321, 1309-1313, 2008.

Shaw, G. E.: Sun photometry, B. Am. Meteorol. Soc., 64, 4-11, 1983.
Smirnov, A., Villevalde, Y., O’Neill, N. T., Royer, A., and Tarussov, A.: Aerosol optical depth over the oceans: Analysis in terms of synoptic air mass types, J. Geophys. Res., 100, 16639-16650, 1995.

Smirnov, A., Holben, B. N., Dubovik, O., O’Neill, N. T., Remer, L. A., Eck, T. F., Slutsker, I., and Savoie, D.: Measurement of atmospheric optical parameters on U.S. Atlantic coast sites, ships, and Bermuda during TARFOX, J. Geophys. Res., 105(D8), 98879901, 2000.

Smirnov, A., Holben, B. N., Eck, T. F., Dubovik, O., Slutsker, I.: Effect of wind speed on columnar aerosol optical properties at Midway Island, J. Geophys. Res., 108(D24), 4802, doi:10.1029/2003JD003879, 2003.

Storelvmo, T., Kristjansson, J. E., Ghan, S. J., Kirkevag, A., and Seland, $\varnothing$, and Iversen, T.: Predicting cloud droplet number concentration in CAM-Oslo, J. Geophys. Res., 111, D24208, doi:10.1029/2005JD006300, 2006.

Sue, W., Schuster, G. L., Loeb, N. G., Rogers, R. R., Ferrare, R. A., Hostetler, C. A., Hair, J. W., and Obland, M. D.: Aerosol and cloud interaction observed from high spectral resolution lidar data, J. Geophys. Res., 13, D24202, doi:10.1029/2008JD010588, 2008.

Tanre, D., Kaufman, Y. J., Herman, M., and Mattoo, S.: Remote sensing of aerosol properties over oceans using the MODIS/EOS spectral radiances, J. Geophys. Res., 102, 16971-16988, 1997.

Torres, O., Bhartia, P. K., Herman, J. R., Ahmad, Z., and Gleason, J.: Derivation of aerosol properties from satellite measurements of backscattered ultraviolet radiation: Theoretical basis, J. Geophys. Res., 103, 17099-17100, 1998.

Villevalde, Y. V., Smirno, A. V., O’Neill, N. T., Smyshlyaev, S. P., and Yakavlev, V. V.: Measurement of aerosol optical depth in the Pacific Ocean and the North Atlantic, J. Geophys. Res., 99(20), 20983-20988, 1994.

von Hoyningen-Huene, W., Wenzel, K., and Schienbein, S.: Radiative properties of desert dust and its effect on radiative balance, J. Aerosol Sci., 30(4), 489-502, 1999. 